Sri Lanka J. Aquat. Sci. 13 (2008): 63-81

\title{
Heavy metal levels in two food fish species from Negombo estuary, Sri Lanka: Relationships with the body size
}

\author{
H.A.P. INDRAJITH ${ }^{1}, \quad$ K.A.S. PATHIRA TNE* AND A. \\ PATHIRA TNE
}

${ }^{1,2}$ Department of Chemistry, Faculty of Science, University of Kelaniya, Kelaniya, Sri Lanka

${ }^{3}$ Department of Zoology, Faculty of Science, University of Kelaniya, Kelaniya, Sri Lanka

${ }^{1}$ Present address: SGS Lanka Laboratory Services, 141/7, Vauxhall street, Colombo 2, Sri Lanka.

*Corresponding author (E-mail: kaspathi@kln.ac.lk)

\begin{abstract}
The present study was carried out to assess the levels of eight metals viz. $\mathrm{Pb}, \mathrm{Cu}, \mathrm{Cd}, \mathrm{Ni}, \mathrm{Cr}, \mathrm{Mn}, \mathrm{Hg}$ and $\mathrm{Zn}$ in two species of food fish,Etroplus suratensis and Ambassis commersoni from Negombo estuary. The levels of $\mathrm{Hg}$ were analyzed by cold vapour atomic absorption spectrometry whereas the other metals were analyzed by flame/graphite furnace atomic absorption spectrometry. Total metal levels in muscle, gill and liver tissues of the fish showed a wide range. Accumulation of most metals in the tissues of the fish followed the increasing order, muscle $<$ gills $\leq$ liver. Of the different metal levels detected in the fish, only the level of $\mathrm{Cd}$ in liver tissue of $6 \% \mathrm{oE}$. suratensis and $12 \%$ of $A$. commersoni exceeded the level specified for human consumption by European Union. Interspecies comparisons revealed that mean level of $\mathrm{Zn}$ in the muscle tissue of $A$. commersoni was two fold higher than that of E. suratensis. The levels of metals in the muscle tissue of both fish species were positively correlated with the body weight or body length of the fish. Based on the levels of $\mathrm{Hg}, \mathrm{Pb}$, and $\mathrm{Cd}$ in the fish, edible muscle of both fish species collected from the estuary was found to be safe for human consumption. However, heavy consumption of bigger size fishmay pose a health risk to the consumers as there were strong positive correlations between body weight or body length and metal levels in muscle tissues of both species of fish.
\end{abstract}




\section{Introduction}

Metals are natural components of the aquatic ecosystems. Heavy metals such as copper and zinc are essential for life whereas some metals including mercury, lead and cadmium are biologically non-essential metals which can be toxic to biota even at very low levels. High concentrations of some essential trace metals may become toxic at concentrations which exceed the required limits (Wright and Welbourn 2002). The metal levels in many aquatic ecosystems have been increased due to anthropogenic activities which raises the concerns on metal bioaccumulation and related human health hazards. Hence there is a growing need for monitoring heavy metal pollution and taking necessary steps to manage and remediate ecological damage.

Fish are useful as sentinel species and bioindicators of metal pollution because they can help to understand the risk to the aquatic ecosystem and to humans (Peakall and Burger 2003). Many of the heavy metals are concentrating at different levels in different organs of the fish body. Moreover, biological factors of the fish such as age and body size could play a role in the bioavailability of metals (Peakall and Burger 2003). The use of wild and cultured food fishes as biomonitors of metal pollution in aquatic ecosystems is becoming popular throughout the world (Norrgren et al. 2000; Mansour and Sidky 2002; Bervoets and Blust 2003; Marcovecchio 2004; Begum et al. 2005; Demirak et al. 2005; Storelli et al. 2006; Agarwal et al. 2007; Ploetz et al. 2007). However, only a few studies have been carried out to monitor metal pollution in food fish species in Sri Lanka. It is important to determine the heavy metal levels in commercial food fish in order to evaluate the possible risk of fish consumption.

Negombo estuary is one of the most productive brackish water bodies in Sri Lanka (Silva 1996). The estuary is a very significant fishery centre. It also serves as a shrimp nursery and nutrient source for the coastal sea. In addition, the estuary serves as an anchorage for about $15 \%$ of Sri Lanka's marine fishing fleet including multiday boats and fiberglass boats powered by outboard motors. The estuary has been indiscriminately exploited for commercial, residential and industrial development and as a sink for industrial and domestic waste (CEA 1994). With the rapid industrialization and urbanization in the area, the estuary is becoming polluted with various hazardous chemicals including heavy metals. However, less attention has been given to study heavy metal pollution in Negombo estuary. Most of the people in the Negombo area fulfill their protein requirements using fishery resources in the estuary. However, no baseline data are available with respect to the levels of heavy metals in fishery resources in the estuary Etroplus suratensis (Pearl spot, Iri Koraliya) and Ambassis commersoni (Common glass fish, Katilla) are two resident fish species in the Negombo estuaryE. suratensis is considered as an omnivorous species where as $A$. commersoni is a carnivorous fish (Pethiyagoda 1991). They are consumed by the people in the area as a protein source. The objectives of the present study were (i) to determine the total levels of eight metals viz. $\mathrm{Pb}, \mathrm{Cu}, \mathrm{Cd}, \mathrm{Cr}, \mathrm{Ni}, \mathrm{Mn}, \mathrm{Hg}$ and $\mathrm{Zn}$ in the 
muscle, gills and liver of E. suratensis and A. commersoni inhabiting the estuary and to assess whether edible parts are safe for human consumption (ii) to evaluate relationships (if any) between the accumulated metal levels in the edible tissues and body size of the fish. In addition, levels of the metals in the abiotic components of the estuary viz. water and sediments were determined in order to identify sources of heavy metals.

\section{Materials and Methods}

\section{Sampling and processing of water and sediments for metal analysis}

Water and sediment were sampled from twelve sampling locations (Figure 1) representing north, east, west and south regions of the estuary in 2003. Immediately after, they were transferred to the laboratory, water samples were filtered through $0.45 \mu \mathrm{m}$ membrane filters and filtrate was acidified to $\mathrm{pH}<2$ with analytical grade concentrated $\mathrm{HNO}_{3}$. As sampling through direct aspiration could not be performed using graphite furnace due to high background absorbance, for the metals except mercury, metal extraction was done using the method as described by Lo (1982) with 1\% ammonium pyrrolidine dithiocarbamate and $1 \%$ sodium diethydithiocarbamate. Another set of water samples collected from each sampling site was processed for $\mathrm{Hg}$ analysis using hydride vapour generation system.

The sediment samples were digested using the method described by Cook et al (1997). Except for mercury, the other seven metals in water or sediment samples were analysed using flame or graphite furnace atomic absorption spectrometry as appropriate. Mercury was analysed using cold vapour atomic absorption spectrometry. Standard solutions were prepared using spectrochemical grade metal solution from BDH. Three replicates were obtained for each measurement with background correction. Recovery tests were done to examine the reliability of the test methods. Percentage recoveries obtained for the metals in the sediments ranged from $70 \%$ to $97 \%$.

\section{Sampling and processing of fish for metal analysis}

Fish samples were collected in 2003 from seven locations of the estuary namely Thalahena, Settappaduwa, Pitipana, Kepungoda, Kurana, Liyanagemulla and Kadolkele. In the laboratory, the total length and weight of the fish were recorded. Muscle, liver and gill tissue were homogenized separately and divided into two portions for wet and dry ashing. For determination of $\mathrm{Pb}, \mathrm{Cu}, \mathrm{Cd}, \mathrm{Cr}, \mathrm{Mn}, \mathrm{Ni}$ and $\mathrm{Zn}$ the samples were ashed according to the method described by Jorhem (1993). Digested fish samples were analyzed using graphite furnace atomic absorption spectrometry. Wet ashing was carried out for $\mathrm{Hg}$ analysis according to the method given by Association of Analytical Chemists (AOAC 2002). Hg in the digested fish samples was analysed using cold vapour atomic absorption spectrometry. A known volume of standard solution was added into the analyte and samples 
were processed according to the same procedures. Percentage recoveries obtained for the metals were in the range of $89 \%$ to $96 \%$.

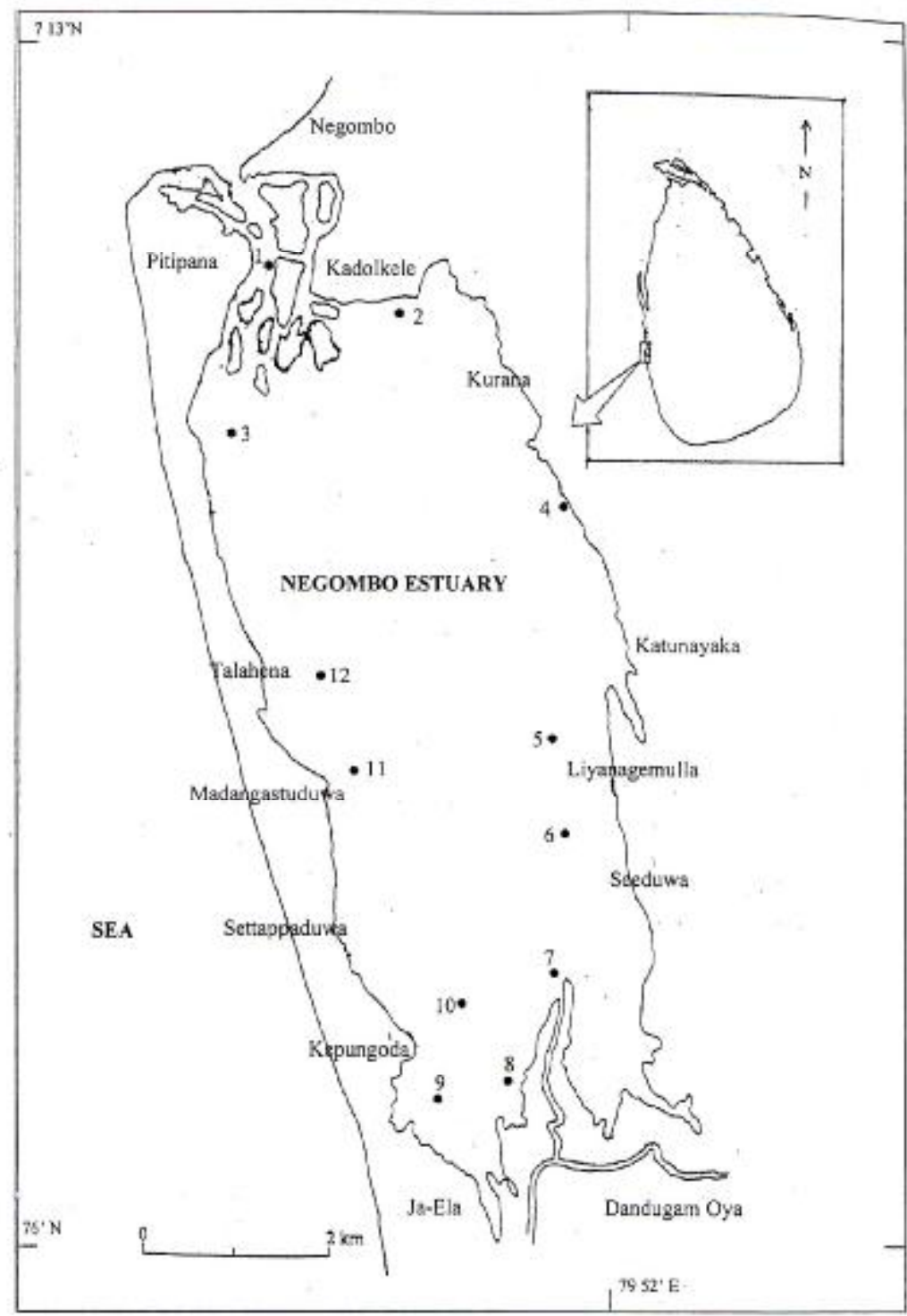

Figure 1. Locations of the sampling sites of the Negombo estuary

\section{Data analysis}

Differences in the level of each metal in water, sediment and the two species of fish collected from the estuary were tested by one way analysis of variance (ANOV A). Where differences were significant, mean values were compared by Tukey's test. Students' t test was used in the inter species 
comparisons. Correlations between body weight of the fish and metal content in the muscle tissue of the two species were assessed by Pearson's correlation test. The relationships between the metal level and body length or body weight were also determined by linear regression analysis. Log transformed data were used in the data analysis. Statistical analysis was carried out as described by Zar (1996). For analysis of body size relationships further, the allometric approach (Weathery and Gill 1987) was applied in which slope of log-log regression of the relationships between total metal burden and body weight or length when compared with slope $=1$ (for body weight) or slope $=3$ ( for total length), is a good predictor for isometric or allometric increase of these metals with increasing body weight or length. $\mathrm{P}<0.05$ was considered as statistically significant.

\section{Results}

\section{Metal levels in water and sediments}

The levels of eight metals in water at 12 sampling sites of the estuary are presented in Table 1 . The concentration (in $\mu \mathrm{g} \mathrm{L}$ ) of the metals in water showed a wide range: $\mathrm{Pb}$, not detected-5.7; $\mathrm{Cu}$, not detected-2.5; $\mathrm{Cd}$, not detected -2.1; Mn, not detected-0.9; Ni, not detected -7.4; $\mathrm{Cr}, 0.9-1.2 ; \mathrm{Hg}$, below the detection limit; and $\mathrm{Zn}, 40.4-180.4$. The detection limits (in $\mu \mathrm{g} \mathrm{L}^{\mathrm{l}}$ ) of the techniques for $\mathrm{Pb}, \mathrm{Cu}, \mathrm{Cd}, \mathrm{Mn}, \mathrm{Ni}$, and $\mathrm{Hg}$ are $0.5,0.5,0.2,0.2,0.5$, and 10 respectively.

The sampling sites 1, 2 and 3 were located in the north region of the estuary whereas the sites 7, 8,9 and 10 were located in the south region (Figure 1). The sites 4, 5 and 6 were located in the east region and the sites 11 and 12 were in the west region. The results indicate that the levels of $\mathrm{Pb}, \mathrm{Cu}$ and $\mathrm{Cd}$ in water were comparatively low in the south region of the estuary. The levels of these metals in the west and east regions were similar or lower than the levels in the north region. No prominent site related differences were found with respect to the levels of $\mathrm{Cr}$ in water. In addition, the levels of $\mathrm{Pb}$ and $\mathrm{Cu}$ in water appear to be high in the east side of the estuary compared to the west side.

The sediment associated metals in the estuary (in $\mathrm{mg} \mathrm{kg}^{-1}$ dry weight) showed irregular distribution of metal contamination reflecting many metal inputs (Table 2). The ranges of the concentrations of all eight metals (in $\mathrm{mg}$ $\mathrm{kg}^{-1}$ ) in sediments were: $\mathrm{Pb}, 4.8-20.1 ; \mathrm{Cu}, 5.3-24.2 ; \mathrm{Cd}, 0.03-0.22 ; \mathrm{Mn}$, 121.9-792.5; Ni, 9.2 -34.7; Cr, 19.2-73.5; Hg, 0.3-2.2 and $\mathrm{Zn}, 119.5-207.4$. The highest level of $\mathrm{Cd}$ in the sediments was found at the sampling site 1 located in the North region whereas levels of $\mathrm{Pb}$ and $\mathrm{Ni}$ were high in the site located in the south region (site 7). $\mathrm{Cu}$ and $\mathrm{Hg}$ levels were the highest in the sediments collected from the east region (sites 5 and 4 respectively). $\mathrm{Mn}, \mathrm{Cr}$ and $\mathrm{Zn}$ levels were high in the sampling sites located in the west region of the estuary. In general, $\mathrm{Mn}$ and $\mathrm{Zn}$ levels in the sediments were very high at all sites compared to the level of the other metals. 


\section{Metal levels in fish}

Total metal levels in muscle tissue (in $\mathrm{mg} \mathrm{kg}$ wet weight) of the two species are presented in Table 3 . The ranges of the concentrations of metals in the edible muscle tissues were: $\mathrm{Pb} 0.01-0.08 ; \mathrm{Cu} 0.02$-0.37; $\mathrm{Cd}$ 0.002-0.048; Mn 0.05-0.51; Ni 0.01-0.31; Cr 0.02 -0.28; Hg 0.03-0.33 and Zn $0.03-3.02$ in E. suratensis and $\mathrm{Pb} 0.004-0.06 ; \mathrm{Cu} 0.01-0.25$; $\mathrm{Cd} 0.001-0.030 ; \mathrm{Mn} 0.01-$ 0.32; Ni 0.01-0.21; Cr 0.01-0.24; $\mathrm{Hg} 0.04-0.26$ and $\mathrm{Zn} \mathrm{0.07-2.56} \mathrm{in} A$. commersoni. Accumulation of most metals in the tissues of these two species followed the increasing order, muscle $<$ gills $\leq$ liver. Inter species comparison of metal levels in muscle tissue of the two fish species revealed that the levels of $\mathrm{Pb}, \mathrm{Cu}, \mathrm{Mn}, \mathrm{Ni}$ and $\mathrm{Cr}$ were significantly lower in the muscle tissue of $A$. commersoni in comparison to those in $E$. suratensis. However, mean level of $\mathrm{Zn}$ in the muscle tissue of $A$. commersoni was two fold higher than that of $E$. surentensis. No significant species-wise differences were found between the two species in relation to the levels of $\mathrm{Cd}$ and $\mathrm{Hg}$ in the muscle and levels of all eight metals in gills and liver tissue of the fish.

\section{Relationships between heavy metal levels and body weight}

The correlations between the levels of selected eight metals in the muscle tissue of both fish species and the body size (body weight and total length) are presented in Table 4. The results show that the accumulation of each metal in the edible muscle is positively correlated with the body length or body weight of the fish. Most of these correlations were highly significant $(\mathrm{P}<$ $0.001)$.

The relationships between body weight or body length and metal level in the muscle tissue of the fish were curvilinear. Regression analysis of the $\log$ metal levels and log body weight or log body length of the fish showed linear relationships with significant correlations in most cases. Figures 2 and 3 present the linear relationships between log metal levels in the muscle tissue and $\log$ body weight or log total length of the fish with respect to an essential metal, $\mathrm{Cu}$ (Figure 2) and for non-essential metal, Hg (Figure 3). Slope of log$\log$ regression of the relationship between $\mathrm{Cu}$ level in muscle tissue o $E$. suratensis and total body weight was 1.049 which was not significantly different from 1 indicating that $\mathrm{Cu}$ level increases in direct proportion to an increase in body weight showing isometry. The slope of the log-log regression of the relationship between $\mathrm{Cu}$ level of this fish and total length was 2.89 which was not significantly different from 3 also indicating the isometric relationship. Other metals in E. suratensis and all the eight metals in $A$. commersoni also showed increase in metal concentration with increase in body length or body weight. However, the slopes of the regression lines between the other metals and body weight or total length were significantly different from 1 (for body weight) or 3 (for total length) showing positive allometric relationships. 
Table 1. The levels of selected metals in water at 12 sampling sites of Negombo estuary.

\begin{tabular}{|c|c|c|c|c|c|c|c|c|c|c|c|c|}
\hline \multirow[t]{2}{*}{ Metal } & \multicolumn{12}{|c|}{ Metal levels $\left(\mu \mathrm{g} \mathrm{L}^{-1}\right)$} \\
\hline & Site 1 & Site 2 & Site 3 & Site 4 & Site 5 & Site 6 & Site 7 & Site 8 & Site 9 & Site 10 & Site 11 & Site 12 \\
\hline $\mathrm{Pb}$ & 5.2 & 5.7 & 3.6 & 1.1 & 1.4 & 1.0 & $-*$ & $-*$ & $-*$ & $-*$ & $-*$ & $-*$ \\
\hline $\mathrm{Cu}$ & 2.5 & 2.1 & 0.6 & 1.1 & 1.7 & 1.6 & $-*$ & $-*$ & $-*$ & $-*$ & $-*$ & 1.0 \\
\hline $\mathrm{Cd}$ & 1.4 & 2.1 & 0.6 & 0.9 & 1.9 & 0.9 & $-*$ & $-*$ & $-*$ & $-*$ & 1.5 & 1.1 \\
\hline $\mathrm{Mn}$ & 0.8 & $-*$ & $-*$ & 0.8 & 0.8 & 0.8 & 0.7 & 0.7 & 0.6 & $-*$ & 0.8 & 0.9 \\
\hline $\mathrm{Ni}$ & 2.2 & $-*$ & 7.4 & 2.1 & 2.1 & 1.7 & 1.4 & 1.5 & 1.15 & 1.1 & 1.3 & 2.1 \\
\hline $\mathrm{Cr}$ & 1.0 & 1.2 & 1.1 & 1 & 1.1 & 0.9 & 1.0 & 0.9 & 0.9 & 1.0 & 1.0 & 1.0 \\
\hline $\mathrm{Hg}$ & -* & -* & $-*$ & -* & -* & -* & $-*$ & $-*$ & -* & -* & _* & -* \\
\hline $\mathrm{Zn}$ & 120.1 & 130.1 & 40.4 & 110.1 & 50.1 & 141.2 & 112.0 & 81.1 & 84.2 & 61.1 & 180.4 & 41.2 \\
\hline
\end{tabular}

*Below the detection limits: $\mathrm{Pb}, \mathrm{Cu} \& \mathrm{Ni} 0.05 \mu \mathrm{g} \mathrm{L} \mathrm{L}^{-1}, \mathrm{Cd} \& \mathrm{Mn} 0.02 \mu \mathrm{g} \mathrm{L}{ }^{-1}, \mathrm{Hg} 10 \mu \mathrm{g} \mathrm{L}{ }^{-1}$ 
Table 2. The levels of selected metals in sediments at 12 sampling sites of Negombo estuary.

\begin{tabular}{llllllllllllll}
\hline Metal & \multicolumn{1}{c}{ Metal levels $\left(\mathrm{mg} \mathrm{kg}^{-1}\right)$} \\
\cline { 2 - 10 } & Site 1 & Site 2 & Site 3 & Site 4 & Site 5 & Site 6 & Site 7 & Site 8 & Site 9 & Site 10 & Site 11 & Site 12 \\
\hline $\mathrm{Pb}$ & 5.1 & 4.8 & 5.6 & 10.7 & 15.0 & 13.9 & 20.1 & 7.4 & 12.5 & 5.9 & 16.5 & 12.1 \\
$\mathrm{Cu}$ & 6.6 & 5.3 & 6.2 & 11.8 & 24.2 & 16.4 & 16.7 & 12.6 & 9.4 & 6.1 & 6.2 & 13.4 \\
$\mathrm{Cd}$ & 0.22 & 0.17 & 0.11 & 0.07 & 0.09 & 0.04 & 0.03 & 0.07 & 0.03 & 0.05 & 0.04 & 0.05 \\
$\mathrm{Mn}$ & 121.9 & 137.5 & 298.5 & 284.1 & 276.2 & 498.8 & 276.1 & 331.4 & 303.4 & 305.9 & 792.6 & 670.4 \\
$\mathrm{Ni}$ & 15.5 & 24.9 & 13.5 & 10.6 & 17.1 & 19.2 & 30.7 & 17.3 & 9.2 & 14.7 & 29.7 & 34.7 \\
$\mathrm{Cr}$ & 36.8 & 58.6 & 33.8 & 26.3 & 28.2 & 32.4 & 47.5 & 38.9 & 19.2 & 46.8 & 55.9 & 73.5 \\
$\mathrm{Hg}$ & 0.6 & 0.6 & 0.5 & 2.2 & 0.7 & 0.6 & 0.3 & 1.4 & 0.3 & 0.5 & 0.51 & 0.75 \\
$\mathrm{Zn}$ & 120.5 & 119.5 & 133.6 & 145.6 & 201.5 & 172.8 & 161.1 & 141.1 & 148.3 & 126.5 & 207.4 & 176.5 \\
\hline
\end{tabular}


Table 3. The level of selected metals in different tissues oEtroplus suratensis and Ambassis commersoni from Negombo estuary

\begin{tabular}{lccc}
\hline \multicolumn{1}{c}{ Metals } & \multicolumn{1}{c}{ Metals levels in $\mathrm{mg} \mathrm{kg}^{-1}$ (wet weight) } \\
\hline \multicolumn{1}{c}{ Etroplus suratensis $(\mathrm{n}=150)$} & \multicolumn{1}{c}{ Gills } & Liver \\
$\mathrm{Pb}$ & $0.03 \pm 0.001(0.01-0.08)^{1}$ & $0.05 \pm 0.004(0.02-0.08)^{2}$ & $0.07 \pm 0.004(0.04-0.09)^{2}$ \\
$\mathrm{Cu}$ & $0.13 \pm 0.006(0.02-0.37)^{1}$ & $0.23 \pm 0.03(0.10-0.41)^{2}$ & $0.41 \pm 0.05(0.15-0.74)^{2}$ \\
$\mathrm{Cd}$ & $0.011 \pm 0.001(0.002-0.048)^{1}$ & $0.027 \pm 0.002(0.017-0.042)^{2}$ & $0.027 \pm 0.003(0.011-0.06)^{2 *}$ \\
$\mathrm{Mn}$ & $0.12 \pm 0.007(0.05-0.51)^{1}$ & $0.11 \pm 0.007(0.06-0.17)^{1}$ & $0.42 \pm 0.03(0.16-0.66)^{2}$ \\
$\mathrm{Ni}$ & $0.05 \pm 0.004(0.01-0.31)^{1}$ & $0.09 \pm 0.005(0.05-0.12)^{2}$ & $0.11 \pm 0.01(0.09-0.20)^{2}$ \\
$\mathrm{Cr}$ & $0.07 \pm 0.003(0.02-0.28)^{1}$ & $0.20 \pm 0.02(0.09-0.33)^{2}$ & $0.39 \pm 0.05(0.05-0.86)^{3}$ \\
$\mathrm{Hg}$ & $0.10 \pm 0.005(0.03-0.33)^{1}$ & $0.18 \pm 0.02(0.10-0.42)^{2}$ & $0.51 \pm 0.03(0.31-0.79)^{3}$ \\
$\mathrm{Zn}$ & $0.50 \pm 0.04(0.03-3.02)^{1}$ & $2.13 \pm 0.26(1.12-5.12)^{2}$ & $4.55 \pm 0.43(1.24-8.71)^{3}$ \\
\hline
\end{tabular}

Table 3 Continued on page 72 
Table 3. Continued from page 71

\begin{tabular}{|c|c|c|c|}
\hline \multirow[t]{2}{*}{ Metals } & \multicolumn{3}{|c|}{ Metals levels in $\mathrm{mg} \mathrm{kg}^{-1}$ (wet weight) } \\
\hline & Muscle & Gills & Liver \\
\hline \multicolumn{4}{|c|}{ Ambassis commersoni $(\mathrm{n}=95)$} \\
\hline $\mathrm{Pb}$ & $0.02 \pm 0.001(0.004-0.06)^{1^{* *}}$ & $0.04 \pm 0.003(0.01-0.07)^{2}$ & $0.07 \pm 0.006(0.02-0.10)^{3}$ \\
\hline $\mathrm{Cu}$ & $0.08 \pm 0.005(0.01-0.25)^{1^{* *}}$ & $0.19 \pm 0.02(0.07-0.32)^{2}$ & $0.38 \pm 0.04(0.12-0.74)^{3}$ \\
\hline $\mathrm{Cd}$ & $0.013 \pm 0.005(0.001-0.030)^{1}$ & $0.027 \pm 0.002(0.014-0.045)^{2}$ & $0.034 \pm 0.003(0.018-0.065)^{2^{*}}$ \\
\hline $\mathrm{Mn}$ & $0.10 \pm 0.01(0.01-0.32)^{1 * *}$ & $0.11 \pm 0.01(0.05-0.19)^{1}$ & $0.35 \pm 0.01(0.30-0.48)^{2}$ \\
\hline $\mathrm{Ni}$ & $0.03 \pm 0.003(0.01-0.21)^{1^{* *}}$ & $0.09 \pm 0.005(0.03-0.14)^{2}$ & $0.11 \pm 0.01(0.07-0.21)^{2}$ \\
\hline $\mathrm{Cr}$ & $0.05 \pm 0.005(0.01-0.24)^{1^{* *}}$ & $0.22 \pm 0.02(0.01-0.47)^{2}$ & $0.32 \pm 0.06(0.10-0.74)^{2}$ \\
\hline $\mathrm{Hg}$ & $0.10 \pm 0.005(0.04-0.26)^{1}$ & $0.24 \pm 0.03(0.05-0.62)^{2}$ & $0.53 \pm 0.05(0.14-0.85)^{3}$ \\
\hline $\mathrm{Zn}$ & $0.83 \pm 0.05(0.07-2.56)^{1 * *}$ & $2.95 \pm 0.27(0.90-6.53)^{2}$ & $3.85 \pm 0.53(1.23-7.84)^{2}$ \\
\hline
\end{tabular}

Results are presented as mean \pm standard error of the mean, ranges (lowest value-highest value). For each row means not followed by the same superscript are significantly different from each other (ANOV A, Tukey's tesk B.05). Log transformed data $\{\log (\mathrm{x}+1)\}$ were used for the statistical analysis.

* $6 \%$ of the samples of E. suratensis and $12 \%$ of the $A$. commersoni samples exceeded the maximum permissible limit for Cd $\left(0.05 \mathrm{mg} \mathrm{kg}^{-1}\right)$.

** Significantly different fromE. suratensis (Students' t test, $\alpha=0.05$ ). 
Table 4. Pearson correlation coefficients for the relationships between metal levels and body size* ofEtroplus suratensis and Ambassis commersoni

\begin{tabular}{llcl}
\hline \multirow{3}{*}{ Metal } & \multicolumn{2}{l}{ Body weight and metal level } & \multicolumn{2}{l}{ Body length and metal level } \\
\cline { 2 - 4 } & $\begin{array}{l}\text { correlation } \\
\text { coefficient }\end{array}$ & P value & $\begin{array}{l}\text { correlation } \\
\text { coefficient }\end{array}$ \\
\hline
\end{tabular}

\section{Etroplus suratensis}

$\begin{array}{lllll}\mathrm{Pb} & 0.500 & 0.001 & 0.472 & 0.001 \\ \mathrm{Cu} & 0.729 & 0.001 & 0.742 & 0.001 \\ \mathrm{Cr} & 0.184 & 0.05 & 0.233 & 0.05 \\ \mathrm{Cd} & 0.773 & 0.001 & 0.745 & 0.001 \\ \mathrm{Mn} & 0.568 & 0.001 & 0.609 & 0.001 \\ \mathrm{Ni} & 0.767 & 0.001 & 0.794 & 0.001 \\ \mathrm{Zn} & 0.726 & 0.001 & 0.716 & 0.001 \\ \mathrm{Hg} & 0.850 & 0.001 & 0.859 & 0.001\end{array}$

\section{Ambassis commersoni}

$\begin{array}{lllll}\mathrm{Pb} & 0.770 & 0.001 & 0.759 & 0.001 \\ \mathrm{Cu} & 0.843 & 0.001 & 0.825 & 0.001 \\ \mathrm{Cr} & 0.704 & 0.01 & 0.775 & 0.001 \\ \mathrm{Cd} & 0.224 & 0.05 & 0.237 & 0.05 \\ \mathrm{Mn} & 0.814 & 0.001 & 0.745 & 0.001 \\ \mathrm{Ni} & 0.614 & 0.001 & 0.667 & 0.001 \\ \mathrm{Zn} & 0.830 & 0.001 & 0.828 & 0.001 \\ \mathrm{Hg} & 0.940 & 0.001 & 0.982 & 0.001\end{array}$

*E. suratensis: body weight 47.0-140.6 g, body length $10.3-17.6 \mathrm{~cm}, \mathrm{n}=114-$ 118, A. commersoni body weight $21.3-91.7 \mathrm{~g}$, body length $5.2-11.2 \mathrm{~cm}$, $\mathrm{n}=91-94$

\section{Discussion}

Water quality of Negombo estuary is influenced by several inland water sheds (Dadugam oya and Hamilton canal) and the sea. The fresh water canals and the tidal floods may transport toxic pollutants originating in different parts of the catchments, land use or in the estuary itself. The estuary is susceptible to chemical pollution due to ongoing development activities of Negombo and Katunayake areas (CEA 1994). Estuary water is not utilized for human consumption because of its salty nature. However, monitoring the status of metal pollution in Negombo estuary would be important to human health because of the fishery of the estuary. Metal level of water and sediment directly relate to the aquatic life of the estuary. Metals may enter the resident fish in different ways and absorbed metals could accumulate in various organs 
of the fish body. The present study provides baseline data with respect to the eight metals viz. $\mathrm{Pb}, \mathrm{Cu}, \mathrm{Cd}, \mathrm{Cr}, \mathrm{Mn}, \mathrm{Ni}, \mathrm{Hg}$ and $\mathrm{Zn}$ in water and sediments of the Negombo estuary as well as for the two species of food fish available in the estuary.

In the present study it was revealed that spatial variations exist in different regions of the estuary, with respect to the dissolved total metals in water: $\mathrm{Pb}, \mathrm{Cu}, \mathrm{Cd}, \mathrm{Mn}, \mathrm{Ni}$, and $\mathrm{Zn}$. In general, the levels of $\mathrm{Pb}, \mathrm{Cu}$, and $\mathrm{Ni}$ in water collected from some sampling sites located in the north region were higher compared to those of the other sites. North region of the estuary is being polluted due to various anthropogenic activities such as solid waste dumping, waste from industries, slaughter houses, shrimp farms, and hatcheries and boat yards. High levels of $\mathrm{Pb}$ in water samples collected from the north region in comparison to those in the other sampling sites may be partly due to the discharge of burned and unburned fuel from motor boats to the estuary water. The north region of the estuary is connected to the sea and it receives water from sea as well. Though the levels of $\mathrm{Pb}, \mathrm{Cu}$ and $\mathrm{Ni}$ in water in all or some sampling sites in this region were higher than those in the other sites, the levels of sediments bound $\mathrm{Pb}$ and $\mathrm{Zn}$ were comparatively low. The status of the sediment of this area is continuously being affected by tidal waves, sedimentation and human activities. Hence the level of metals in the sediments of this area is subjected to change through out the year and this may have partly contributed to low $\mathrm{Pb}$ and $\mathrm{Zn}$ accumulation in sediment of this area in comparison to the other sites.

The sampling sites 7, 8, 9 and 10 are located in the south region. This region receives water mainly from the Hamilton canal and Dadugam oya and they carry various effluents from Ekala industrial zone (CEA 1994). In comparison to the north region of the estuary, the levels of metals in water of south region $(\mathrm{Pb}, \mathrm{Cu}, \mathrm{Cd}$, and $\mathrm{Mn})$ were low but the levels of metals in sediments $(\mathrm{Pb}, \mathrm{Cu}, \mathrm{Zn}$, and $\mathrm{Mn})$ were higher in some sampling sites compared to the metal levels in the sites located in the north region. West region (sampling sites 11 and 12) receives waste from hotels, shrimp farms and fish processing industries: Generally the levels of $\mathrm{Pb}$ and $\mathrm{Cu}$ in water of this area were low but the levels of sediment bound metals ( $\mathrm{Pb}, \mathrm{Cu}, \mathrm{Mn}, \mathrm{Ni}, \mathrm{Cr}$ and $\mathrm{Zn}$ ) were comparatively high. East region (Sites 4, 5 and 6) receives effluent from mainly Katunayake industrial processing zone, hotels and a housing scheme. Hence the levels of metals in water $(\mathrm{Pb}, \mathrm{Cu}, \mathrm{Ni}$ and $\mathrm{Zn})$ sampled from this area were relatively high.

Accumulation of metals in different fish species depends on the bioavailable metal concentrations in the abiotic components of their habitats, their feeding habits, ecological needs, metabolism, age and size of the fish (Peakall and Burger 2003; Marcovecchio 2004). Observed wide ranges of specific metal levels detected in the fish collected from the estuary may indicate that these fish had been exposed to a mixture of metals with different bioavailabilities within the estuary through water, sediments and food items. 
(a) Etroplus suratensis
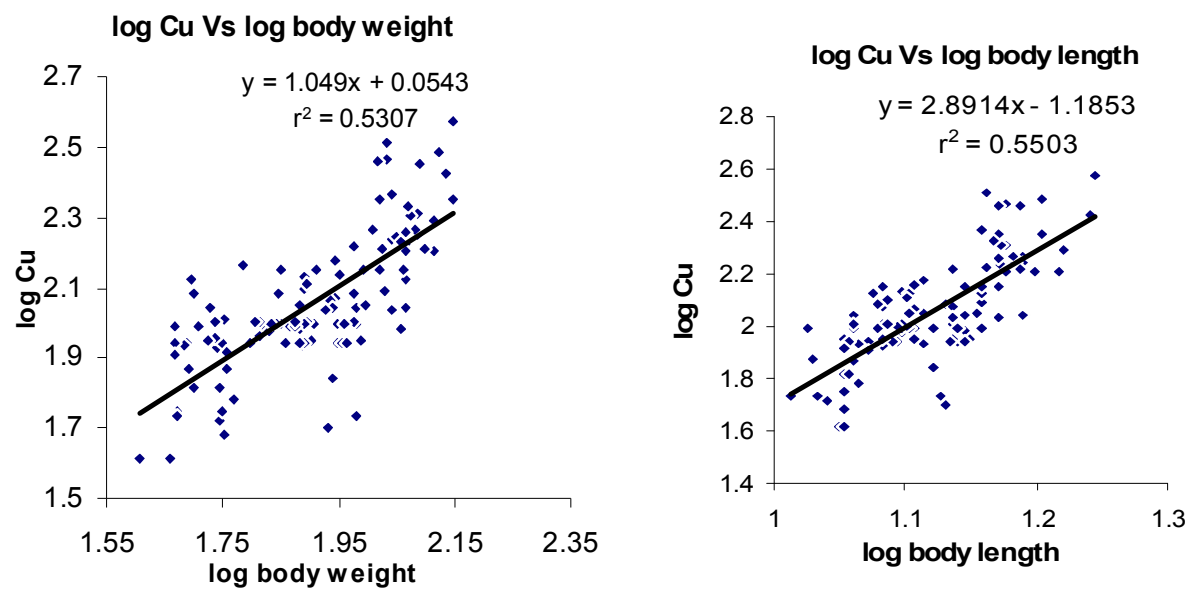

(b) Ambassis commersoni
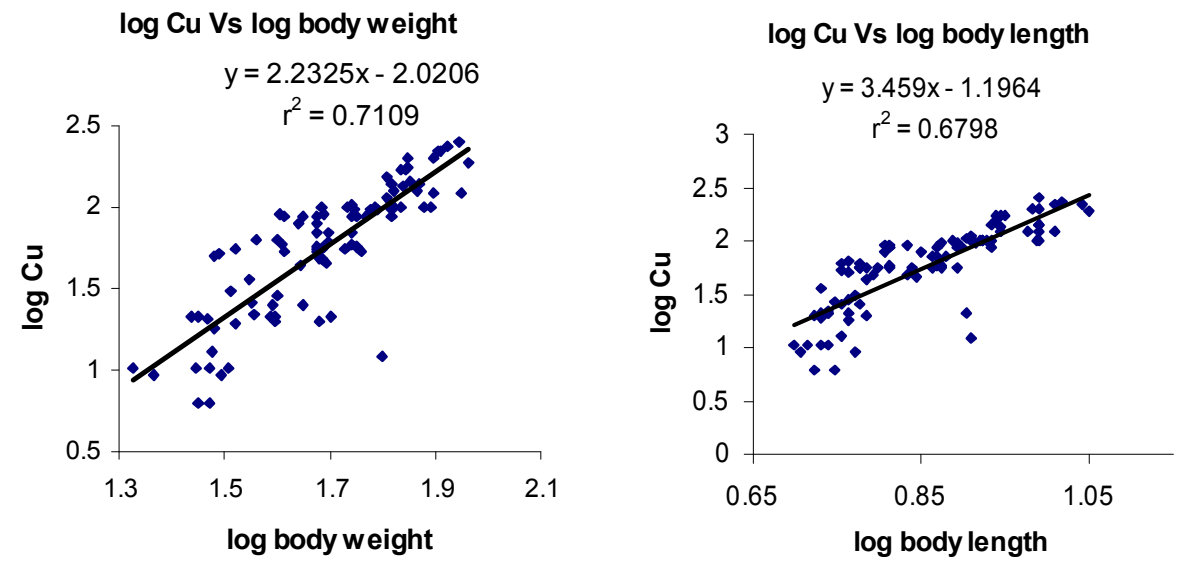

Figure 2. Relationship between copper level in muscle tissue and log body weight of Etroplus suratensis and Ambassis commersoni from Negombo estuary 
(a) Etroplus suratensis

$\log \mathrm{Hg}$ Vs log body weight

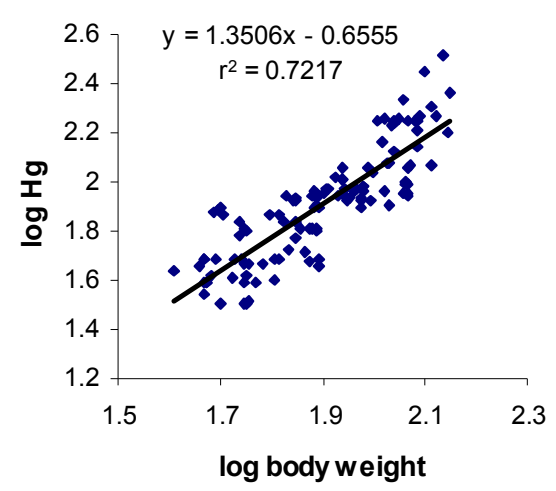

(b) Ambassis commersoni

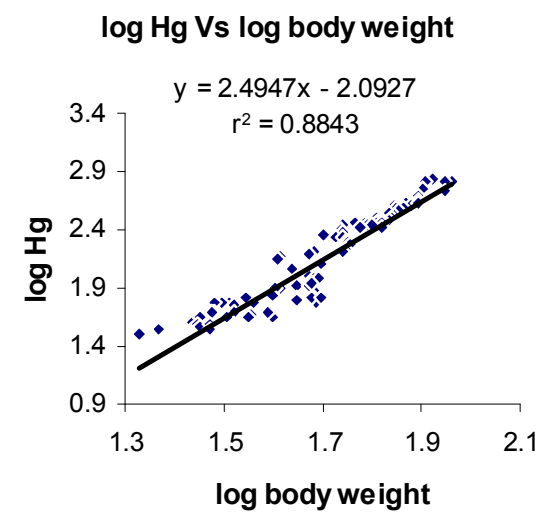

$\log \mathrm{Hg}$ Vs log body length

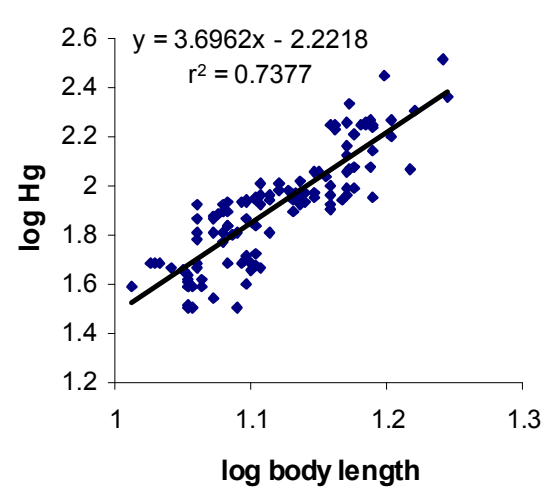

$\log \mathrm{Hg}$ Vs log body length

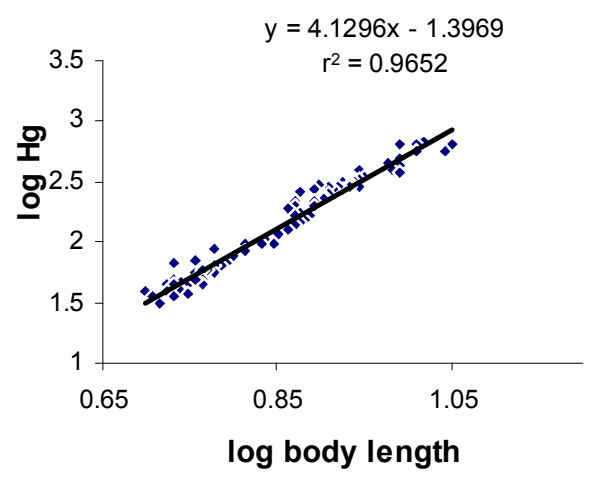

Figure 3. Relationship between mercury level in muscle tissue and log body weight of Etroplus suratensis and Ambassis commersoni from Negombo estuary

In the present study, results of the measured metals of the two species followed the order, muscle $<$ gill $\leqslant$ liver showing different metal accumulation capacities of these tissues of $E$. suratensis and $A$. commersoni from Negombo estuary. The results of this study show that the muscle tissue of these fish is not an active organ in accumulating heavy metals. Metal levels in liver reflect 
the high metal storage capacity of the organ. Liver stores heavy metals by producing metallothioneins which appears as a metal detoxification mechanism within the body (Roesijadi and Robinson 1994; Peakall and Burger 2003). Metallothioneins are a family of low molecular weight cystein rich proteins that occur in the animals. Their synthesis can be induced by a wide variety of metal ions including cadmium, copper, and zinc. In the present study gill tissues of the fish collected from several occasions also had high metal contents comparable to liver tissues. In general the concentrations of metals in the gills may reflect the concentration of metals in water. Metal concentrations in the gills could also be due to complexing of the elements with mucus remaining between the gill lamella, which is hard to remove completely from the gills before preparation of the tissue for analysis (Demirak et al. 2005). The accumulation of metals in gills and liver of food fish do not directly affect human health because these are not edible parts. Nevertheless the predatory animals such as birds who consume the whole fish from the estuary are at risk of excess metal contamination.

$\mathrm{Pb}, \mathrm{Cd}$, and $\mathrm{Hg}$ are biologically non essential- metals which are accumulated in human tissues and harmful to human health. The level of $\mathrm{Pb}$, $\mathrm{Cd}$ and $\mathrm{Hg}$ in the edible muscle of $E$. suratensis collected from Negombo estuary ranged from $0.01-0.08,0.002-0.048$ and $0.03-0.33 \mathrm{mg} \mathrm{kg}^{-1}$ wet weight respectively. Corresponding values for edible muscle ofl. commersoni were $0.004-0.06,0.001-0.030$ and $0.04-0.26 \mathrm{mg} \mathrm{kg}^{-1}$ wet weight. The maximum allowable levels of $\mathrm{Pb}, \mathrm{Cd}$ and $\mathrm{Hg}$ in the fish for human consumption specified by the European Union are $0.2,0.05$ and $1 \mathrm{mg} \mathrm{kg}$ wet weight respectively (EU 2002). Of the different metal levels detected inE. suratensis and $A$. commersoni the levels of the three metals in the edible muscle of all the fish collected from Negombo estuary did not exceed these allowable limits in fish for human consumption specified by European Union. However, the liver tissue of $6 \%$ of E. suratensis and $12 \%$ of $A$. commersoni collected from the estuary exceeded the limit for $\mathrm{Cd}$. The maximum levels of $\mathrm{Pb}, \mathrm{Cd}$, and $\mathrm{Hg}$ in food fish specified by the EU are lower than the other international standards for food. According to the median international standards for food the tolerable levels for $\mathrm{Pb}$, and $\mathrm{Cd}$ in food are 2 and 0.3 $\mathrm{mg} \mathrm{kg}^{-1}$ wet weight respectively (Philips 1993). The metal levels in the fish from Negombo estuary were much below these international standards for $\mathrm{Pb}$ and $\mathrm{Cd}$.

$\mathrm{Cu}, \mathrm{Mn}, \mathrm{Ni}, \mathrm{Cr}$ and $\mathrm{Zn}$ are essential metals for the biota and are regulated by physiological mechanisms in most organisms. However, occurrence of excessive levels of them is regarded as potential hazards that can endanger both animal and human health (Wright and W elbourn 2002). The ranges of the levels of $\mathrm{Cu}, \mathrm{Mn}, \mathrm{Ni}, \mathrm{Cr}$ and $\mathrm{Zn}$ in the edible muscle of $E$. suratensis collected from Negombo estuary were $0.02-0.37,0.05-0.51$, $0.01-0.31,0.02-0.28$ and $0.03-3.02 \mathrm{mg} \mathrm{kg}^{-1}$ wet weight respectively. The corresponding values in the muscle of $A$. commersoni were $0.01-0.25,0.01-$ $0.32,0.01-0.21,0.01-0.24$, and $0.07-2.56 \mathrm{mg} \mathrm{kg}^{-1}$ wet weight respectively The median international standard levels of $\mathrm{Cu}, \mathrm{Cr}$ and $\mathrm{Zn}$ in the food for 
human consumption are 20,1 and $45 \mathrm{mg} \mathrm{kg}^{-1}$ wet weight respectively (Philips 1993). The levels of these essential metals in the edible muscle of both species of fish collected from Negombo estuary were much lower than the median international standard levels. Hence, these metal levels have posed no threat for consumption of the fish muscle from the estuary.

A. commersoni is a carnivorous fish whereas E. suratensis is an omnivorous fish which feeds on macrophytes, detritus, diatoms and animal matter (Pethiyagoda 1991). In the present study it was revealed that levels of $\mathrm{Cd}, \mathrm{Cr}, \mathrm{Mn}$, and $\mathrm{Ni}$ in muscle tissues of $E$. suratensis is higher than those of $A$. commersoni. The level of $\mathrm{Zn}$ in the edible muscle of $A$. commersoni was higher than that in E. suratensis. Degree of bioaccumulation of metals in the muscle of these fish may be related to the food and feeding habits of these fish.

Accumulations of $\mathrm{Pb}, \mathrm{Cu}, \mathrm{Cd}, \mathrm{Cr}, \mathrm{Hg}, \mathrm{Mn}, \mathrm{Ni}$ and $\mathrm{Zn}$ in the muscle tissue of these two fish species were positively correlated with the body weight and body length. Further, slope of log-log regression of the relationship between $\mathrm{Cu}$ level in muscle tissue of $E$. suratensis and total body weight was not significantly different from 1 indicating that the metal level increase in direct proportion to an increase in body weight showing isometry (W eathery and Gill, 1987). Moreover, the slope of the log-log regression of the relationship between $\mathrm{Cu}$ level of this fish and total length was not significantly different from 3 indicating the isometric relationship. Other metals in $E$. suratensis and all the eight metals in A. commersoni also showed increase in metal concentration with increase in body length or body weight. However, the slopes of the regression lines between the other metals and body weight or total length were significantly different from 1 (for body weight) or 3 (for total length) showing positive allometric relationships (Weathery and Gill 1987). The results suggest that these metals can accumulate in the muscle tissue o $E$. suratensis and A. commersoni at a higher rate compared to the rate of excretion of these metals as the fish grows.

In conclusion, accumulation of metals in the selected two food fish species (E. suratensis and A. commersoni) from Negombo estuary was organ specific and species specific. Generally metal accumulation in tissues of these two species followed the increasing order, muscle $<$ gill $\underline{5}$ liver. Based on the levels of toxic non-essential heavy metalsviz. $\mathrm{Hg}, \mathrm{Pb}$, and $\mathrm{Cd}$ in body muscle of both fish species, the fish muscle was found to be safe for human consumption. The levels of essential metals testedviz. $\mathrm{Cu}, \mathrm{Cr}, \mathrm{Mn}, \mathrm{Ni}$ and $\mathrm{Zn}$ have posed no threat for consumption of the muscle of these fish from the estuary. However, heavy consumption of bigger sizeE. suratensis and $A$. commersoni from the Negombo estuary may pose a health risk to the consumers as there were strong positive correlations between body weight or body length and metal levels in edible muscle tissue of both species of fish. Hence, the necessity of regular monitoring of heavy metal pollution in Negombo estuary is emphasized as there are multiple sources of heavy metal contamination in the vicinity of the estuary. The current study may provide baseline data for water and sediments of Negombo estuary and for fish available from the estuary. More detail study on seasonal trends and spatial 
variations in heavy metal pollution in the Negombo estuary would be useful to locate point and non-point sources of heavy metal pollution and to take necessary steps to manage and remediate the ecological damage.

\section{References}

AOAC, 2002.

Official Methods of Analysis AOAC International. Alternative flameless atomic absorption spectrometric method.

Agarwal, R., R. Kumar \& J. R. Behari 2007.

Mercury and lead content in fish species from the river Gomti, Luknow, India as biomarkers of contamination. Bulletin of Environmental Contamination and Toxicology 78:108-112.

Begum, A., M. N. Amin, S. Kaneco \& K. Onta 2005.

Selected elemental composition of the muscle tissue of three species of fish, Tilapia nilotica, Cirrhina mrigala and Clarius batrachus from the freshwater Dhanmondi Lake in Bangaladesh. Food Chemistry 93:439-443.

Bervoets, L. \& R. Blust 2003.

Metal concentrations in water, sediment and gudgen (Gobio gobio) from a pollution gradient: relationship with fish condition factor. Environmental Pollution 126:9-19.

CEA 1994.

Muthurajawela Marsh and Negombo Lagoon Wetland Conservation Plan, Central Environmental Authority, Sri Lanka.

Cook, J. M, M. J, Garder, A. H Griffith, M. A. Jessep, J. E. Ravenscroft \& R.Y ates 1997.

The comparability of sample digestion techniques for the determination of metals in sediments. Marine Pollution Bulletin 34(8):637-644.

Demirak, A, F.Yilmaz, A. L. Tuna \& N. Ozdemir 2005.

Heavy metals in water, sediment and tissues ofLeuciscus cephalus from a stream in Southwestern Turkey. Chemosphere doi;10.1016/j.chemosphere.2005.09.033

EU, 2002.

The Commission of the European Communities, Commission regulation, (EC) No. 221/2002 amending regulation (EC) No. $466 / 2001$ setting maximum levels for certain contaminants in food stuff in order to protect public health. Official Journal of the European Communities 7.2.2002, L37/5-L37/6

Jorhem, L. 1993.

Determination of metals in foodstuffs by atomic absorption spectrometry after dry ashing; NMKL Inter laboratory study of lead, cadmium, zinc, copper, iron, chromium and nickel. Journal of AOAC International 76(4): 798-815. 
Lo, J.M. 1982.

Solvent extraction of dithiocarbamate complexes and back extraction with Mercury (II) for determination of trace metals in sea water by atomic absorption spectrometry, Analytical Chemistry 5\$2536-2539.

Mansour, S. A. \& M. M. Sidky. 2002.

Ecotoxicological studies. 3. Heavy metal contaminating water and fish from Fayoum Governorate, Egypt. Food Chemistry 78: 15-22.

Marcovecchio, J. E. 2004.

The use of Micropogonias furnieri and Mugil liza as bioindicators of heavy metal pollution in La Plata river estuary, Argentina. Science of the Total Environment 323:219-226.

Norrgren, L, U. Petterson, S. Orn. \& P.A. Bergqvist 2000.

Environmental monitoring of the Kafue River, located in the Copperbelt, Zambia. Archives of Environmental Contamination and Toxicology 38:334-341.

Peakall, D. \& J. Burger 2003.

Methodologies for assessing exposure to metals: speciation, bioavailability of metals \& ecological host factors: Ecotoxicology and Environmental Safety56:110-121.

Pethiyagoda, R. 1991.

Fresh Water Fishes of Sri Lanka, The Wildlife Heritage Trust of Sri Lanka, Colombo, Sri Lanka

Philips, D.J.H. 1993.

Developing country aquaculture - trace chemicals contaminants and public health concerns. In:Environment and Aquaculture in Developing Countries. (R. S. V. Pullin, H. Rosenthal \& J. L Maclean eds.) V ol. 31, pp.296-311. ICLARM Conference Proceedings.

Ploetz, D. M, B.E. Fitts \& T.M. Rice 2007.

Differential accumulation of heavy metals in muscle and liver of a marine fish, (King Mackeral, Scomberomorus cavalla Cuvier) from the Northen Gulf of Mexico, USA. Bulletin of Environmental Contamination and Toxicology78:127.

Roesijadi, G. \& W.E. Robinson 1994.

Metal regulation in aquatic animals: mechanisms of uptake, accumulation and release. In: Aquatic Toxicology: Molecular, Biochemical and Cellular Perspectives. (D. C. Malins \& G. K. Ostrander eds.) pp. 387-420, Lewis Publishers.

Silva, E.I.L 1996.

Water quality of Sri Lanka, A Review of Twelve Water Bodies Institute of Fundamental Studies, Kandy, Sri Lanka.

Storelli, M. M., G. Barone, A. Strelli \& G.O. Marcotrigiano 2006.

Trace metals in tissues of Mugilids (Mugil auratus, Mugil capito and Mugil labrosus) from the Mediterranean Sea. Bulletin of Environmental Contamination and Toxicology 77:43-50.

W eathery, A. H. \& H. S. Gill 1987.

The Biology of Fish Growth. Academic Press. London. 
Wright, D. A. \& P. Welbourn 2002.

Environmental Toxicology, Cambridge press, Cambridge

Zar, J. H. 1996.

Biostatistical Analysis Printice-Hall, Englewood Cliffs, N.J. 